\title{
NOVOS DESAFIOS E NOVOS COMPROMISSOS
}

Acreditamos que, nos últimos anos, a revista TMM se consolidou como uma publicação importante para a comunidade Brasileira do setor mínero-metalúrgico e de materiais. Vimos cumprindo o papel de divulgar nossos avanços científicos e tecnológicos, principalmente no âmbito nacional. Analisando o cenário de nossa área, observamos que, a partir de agora, o progresso da TMM virá somente com a expansão para o âmbito internacional. Isto permitirá divulgar nossos avanços para todo o mundo, assim como ter acesso a informações importantes sobre a tecnologia em uso no exterior. Para isto estamos assumindo alguns novos compromissos com nossos autores e leitores: Em primeiro lugar, vamos acelerar o fluxo de publicação. Nossos editores e revisores reiteraram o compromisso de dedicação à revista e estamos dinamizando os nossos processos para que os autores tenham resposta rápida sobre seus trabalhos. Estamos à disposição para acompanhar os casos de atraso ou dificuldade. Em caso de atraso excessivo, por favor contate os editores!

Aumentamos a quantidade de artigos por número publicado e estamos buscando garantir, em cada número, uma fração significativa de artigos em inglês. Estamos também realizando as mudanças necessárias para, em breve, oferecer um sistema de publicação "on-line" independente da data de lançamento de cada número. Para isto, mais do que nunca, o trabalho voluntário dos editores e revisores é fundamental para o sucesso da nossa publicação. A eles, a revista e a $A B M$ agradecem, mais uma vez, o apoio e dedicação, sem os quais não é possível manter um periódico de qualidade.

Esperamos que com esta nova fase possamos prestar um serviço ainda melhor, elevando, ainda mais, o padrão de nossa Revista.

André Luiz Vasconcellos da Costa e Silva

Editor-Chefe

2176-1523 (c) 2019 Associação Brasileira de Metalurgia, Materiais e Mineração. Publicado pela ABM. Este é um artigo de acesso aberto distribuído sob os termos da licença Creative Commons CC BY-NC-ND (Attribution-NonCommercial-NoDerivs) - https:// creativecommons.org/licenses/by-nc-nd/4.0\%. 